\title{
Forest as a place for recreation but also the source of allergenic plant pollen: to come or avoid?
}

\author{
Tomasz Dudek ${ }^{1} \cdot$ Idalia Kasprzyk ${ }^{2}$ (i) $\cdot$ Agata Dulska-Jeż ${ }^{2}$
}

Received: 19 March 2018 / Revised: 18 September 2018 / Accepted: 3 October 2018 / Published online: 15 October 2018

(c) The Author(s) 2018

\begin{abstract}
For many years, we have observed a significant rise in urban population, the spatial development of cities, and an increase in urbanized areas. More and more people feel the need to have contact with nature. The interest in forest recreation is growing, though the forest is a serious source of allergenic plant pollen. The aim of the present study was to compare two forest types in the context of their recreational potential and the effect strength of aeroallergens. This study was conducted in SE Poland in a Nemoral Scots pine forest (RB) and in a Central European submountainous beech forest (TH). Their recreational potential was assessed. Samples of moss containing plant pollen were collected under the canopy, from forest clearings and forest edges as well as in an open area. Based on the number of pollen grains deposited in moss pollsters, the forest impact on humans was calculated. The recreational potential values for both sites studied are evidence of the high recreational suitability of these forests, but the recreational capacity of RB is lower compared to TH. Palynological analysis showed that the pollen deposition is higher in BR and that the plant pollen risk is lowest under the canopy, regardless of the forest type. The beech forest was found to be characterized by greater recreational potential and a weaker actual effect of pollen allergens than the pine forest. In assessing forest recreational potential, palynological data should form the basis for modification of the degree of recreational suitability. Such information would also be useful in controlling recreational traffic since, as we have proved, visiting appropriate places in a forest allows the exposure of allergen sensitive people to be reduced.
\end{abstract}

Keywords Recreational potential of forest $\cdot$ Allergy $\cdot$ Visiting forests $\cdot$ Outdoor activities $\cdot$ Pollen $\cdot$ Pollen deposition

\section{Introduction}

Due to urbanization and the related spread of urban lifestyle, a very large part of the human population spends most of the time indoor. Therefore, the need to have contact with nature is increasing and nowadays there is a great interest in forest recreation (Lee and Lee 2015), which is accompanied by the growing demand for recreational infrastructure (Wilkes-Allemann et al. 2017). Forests provide

Communicated by Gediminas Brazaitis.

Idalia Kasprzyk

idalia@univ.rzeszow.pl

1 Department of Agroecology, Faculty of Biology and Agriculture, University of Rzeszów, ul. Ćwiklińskiej 1, 35-601 Rzeszow, Poland

2 Department of Ecology and Environmental Biology, Faculty of Biology and Agriculture, University of Rzeszów, ul. Zelwerowicza 4, 35-601 Rzeszow, Poland important recreational services, and popular forms of recreation primarily include forest walking, running, Nordic walking, cycling, and wildlife watching, e.g., birdwatching or butterfly watching, while in winter cross-country skiing (Krzymowska-Kostrowicka 1997; Hansen et al. 2017). In Japan about $36 \%$ of people regularly practice forest walking (Morita et al. 2009). In Poland forest recreation also enjoys great popularity and as much as $76-90 \%$ of people declare their willingness to spend their leisure time in forests (Kikulski 2008; Gołos 2013; Dudek 2016). This situation can be explained by the positive effects of the forest environment on physical and mental health (Karjalainen et al. 2010; Lee and Lee 2015). As a green space, the forest buffers stress and beneficially influences our mental health, forest visits have a positive effect on our concentration and performance and they can even help in the treatment of depressions (Annerstedt et al. 2010; van den Bosch 2017; Kuo 2015). Forest recreation results in reduced pulse and diastolic blood pressure, decreases blood glucose levels in diabetic patients, and also gives the subjective 'feeling of comfort', 'feeling of 
calm', and 'feeling of refreshment' to a much greater extent than in an urban area (Ohtsuka et al. 1998; Park et al. 2009). The above described benefits pose new challenges to forest recreation management (Jay and Schraml 2013) and must be incorporated into forest management planning (Nordström et al. 2015). As far as urban and suburban forests are concerned, their importance for public health has a crucial impact on forest management already today (Wolch et al. 2014). Forests play an important role in reducing air pollutants, in particular including $\mathrm{PM}_{10}$ (particulate matters with an aerodynamic diameter smaller than $10 \mu \mathrm{m}$ ) and $\mathrm{CO}_{2}$ as well as $\mathrm{O}_{3}, \mathrm{SO}_{2}$, and $\mathrm{NO}_{2}$ (Nowak et al. 2006; Escobedo et al. 2011), but at the same time they produce biogenic volatile organic compounds harmful to humans (van den Bosch 2017). Poisonous or thorny plants, insect bites, fires, wildlife damage are one of the forest disservices (Vaz et al. 2017). The literature describes a number of serious health hazards, most of which are associated with tropical forests and only few of them relate to boreal and temperate zone forests. In these areas, the most important threats include Lyme disease and tick-borne encephalitis (Butler 2008; Wójcik-Fatla et al. 2009). However, there is a gap as regards research on forests as a source of allergenic pollen. As a matter of fact, this risk is noticed (Moore et al. 2006; Morita et al. 2009; Vaz et al. 2017), but studies are few and without detailed analysis of palynological data or allergenic flora. Forest is certainly a source of a huge amount of pollen, but there is a lack of reliable data regarding the scale of pollen production by forests and also a lack of research on the negative effects of forest visits by allergy sufferers. Many forest-forming species of the Northern Hemisphere, such as beech, oak, hornbeam, birch, pine, fir, and spruce, are anemophilous and the scale of their pollen production is very large (Subba Reddi and Reddi 1986). It is estimated that one hazel flower produces about 36,000 pollen grains, whereas a single inflorescence almost 9 million (Piotrowska 2008). The pollen released from flowers of a single tree often falls close to the mother plant, but if large vegetation complexes, such as a forest, are the source of pollen, clouds of released pollen can travel substantial distances (Skjøth et al. 2008), thus creating a serious threat to humans due to its allergenic properties. It is now estimated that from 5 to $40 \%$ of the human population is allergic to plant pollen and this percentage is constantly rising, in particular in industrialized urban areas with severe air pollution (Pawankar et al. 2013; Timm et al. 2016). Pollen plant causes a range of disease symptoms, most frequently rhinitis and conjunctivitis, and it can lead to asthma. Nowadays, patients are quite frequently sensitized to the pollen of many plant species that bloom at different times (Pawankar et al. 2013). Among trees found in the temperate climate, the pollen of deciduous trees, predominantly from the Fagales order, i.e., oaks, birches, alders, and hazels, is the most frequent cause of inhalant allergies (Pawankar et al. 2013; Šaulienè et al. 2016). Sensitized people suffer allergic conditions during periods of occurrence of airborne pollen (Šaulienè et al. 2016). In Europe the growing season lasts more than half a year and hence a patient with polyvalent allergy is exposed to health-threatening concentrations of plant pollen over a long period of time (Kasprzyk 2011; Šauliene et al. 2016). Allergy treatment costs are very high and thus prevention, that is, avoiding contact with an allergen, is much desired (Pawankar et al. 2013).

In common opinion, supported by many scientific studies, the forest is considered to be a perfect place for recreation and visiting a forest is recommended for healthy people and also for people suffering from various health conditions (Krzymowska-Kostrowicka 1997; van den Bosch 2017; Karjalainen et al. 2010). Nevertheless, an physician considers whether the forest is safe for his or her patient and whether it is a good place for recreation for this patient. The comparison of the benefits and risks associated with forest visits has been addressed exceptionally rarely, and one of the few examples is a paper regarding visits of allergenic people to a Japanese cedar forest during the pollen season (Morita et al. 2009). These authors stress that despite the fact that even $20 \%$ of the population is allergic to cedar pollen, about $1 / 3$ of people prefer forest recreation ("shinrin-yoku"). The present study deals with similar issues and is a kind of polemic with authors who represent various scientific fields and who perceive the forest from different perspectives.

The main question is how to judge the importance of the forest for visitors, their health and well-being, in times of the growing risk of allergy. It was assumed that the forest could be a potential threat to human health and its impact depends not only on the quantitative and qualitative composition of tree stands, but also on the allergenic potential of forestforming species. As an attempt to address this problem, this study determined the recreational potential of two forest types that are frequently found in the Northern Hemisphere: Nemoral Scots pine forest and Central European submountainous beech forest, as well as the degree of their impact on allergic people based on an analysis of allergenic plant pollen deposited in moss pollsters. The practical objective was to prepare recommendations for people visiting these two forest types and to create a scientific basis for developing a method for determining forest recreational potential based on palynological analysis.

\section{Materials and methods}

\section{Study area}

This study was conducted in forests of southeastern Poland in the Podkarpacie region (Subcarpathia), in two forest complexes: the Bór Nature Reserve (RB, $21^{\circ} 97^{\prime}-22^{\circ} 01^{\prime} \mathrm{E}$, 
$\left.50^{\circ} 11^{\prime}-50^{\circ} 14^{\prime} \mathrm{N}\right)$, which comprises suburban forests of Rzeszów (the largest city of SE Poland with a population of 187,000 inhabitants and an area of $120 \mathrm{~km}^{2}$ ), and about $30 \mathrm{~km} \mathrm{SE}$ in relation to RB - the area of the Tarnawka and Hadle villages (TH, 22 $21^{\prime}-22^{\circ} 28^{\prime} \mathrm{E}, 49^{\circ} 91^{\prime}-49^{\circ} 96^{\prime} \mathrm{N}$; Fig. 1). The study area belongs to two regions: a tectonic basin (Sandomierz Basin) and the Carpathian foothills (Kondracki 2000). Forest cover in Podkarpacie is one of the highest in Poland, about 38\%, while the national average is $29.4 \%$ (Central Statistical Office 2014).

The region's climate has the following characteristics: (1) mean annual temperature: $8.8{ }^{\circ} \mathrm{C}$; (2) mean annual precipitation: $687 \mathrm{~mm}$; (3) mean growing season length: 225-230 days; (4) prevailing wind direction: S-W, W, and $\mathrm{N}-\mathrm{W}$. The warmest month is July when the mean temperature is $19.3^{\circ} \mathrm{C}$, and the total precipitation is about $111 \mathrm{~mm}$. January is the coldest month $\left(-1.9^{\circ} \mathrm{C}\right)$, whereas the lowest precipitation is recorded in February, on mean $33.1 \mathrm{~mm}$ (Tomczyk and Szyga-Pluta 2016, www.tutiempo)

$\mathrm{RB}$ is located in a lowland area, slightly undulating and characterized by small elevation differences. The altitudes are from 205 to $235 \mathrm{~m}$ a.s.1. Brown and podzolic soils formed on Quaternary moraine sands are predominant here (Plan Urządzania Lasu 2010). Under such conditions, moderately fertile habitats have formed, i.e., hemiboreal forests and mixed broadleaved-coniferous forests. The forest stands in the age range from 20 to 110 years are dominated by the pine (age classes III-V). In RB the forest stands consist of the following: Pinus sylvestris (Scots pine), Quercus robur (pedunculate oak), and Fagus sylvatica (European beech). Among the other species, the following are important: Larix decidua (European larch), Betula pendula (common birch), and Carpinus betulus (European hornbeam) (Table 1). The area of $\mathrm{TH}$ is characterized by a more diverse topography where wide ridges with an altitude of $350-450 \mathrm{~m}$ a.s.1. are separated by valleys-150-200 m a.s.l. Brown soils, luvisols, and pseudogley soils prevail here. In this area, one forest habitat type was found, the most fertile upland habitatupland mesic forest. The following species are predominant in the forest stands there: F. sylvatica, Abies alba (European silver fir), $Q$. robur, and $C$. betulus. In the admixture, the following species are found: L. decidua, B. pendula, Acer pseudoplatanus (sycamore maple), Picea abies (Norway spruce), Fraxinus excelsior (ash), and Tilia spp. (lindens). The forest stands where the study was carried out represented age classes from II to VII (Table 2) (Plan Urządzania Lasu 2013).

\section{Determination of forest recreational potential}

Forest recreational potential was assessed using recreational evaluation by the point grading method developed for plain areas (here RB) by the Forest Research Institute by Łonkiewicz and Głuch (1991) (Tables 3, 4). This method evaluates two main criteria: habitat moisture and forest stand age, and it has been positively tested in the forests of central Europe (Kikulski 2006). For the areas of varied orography (here $\mathrm{TH}$ ), the third criterion, terrain

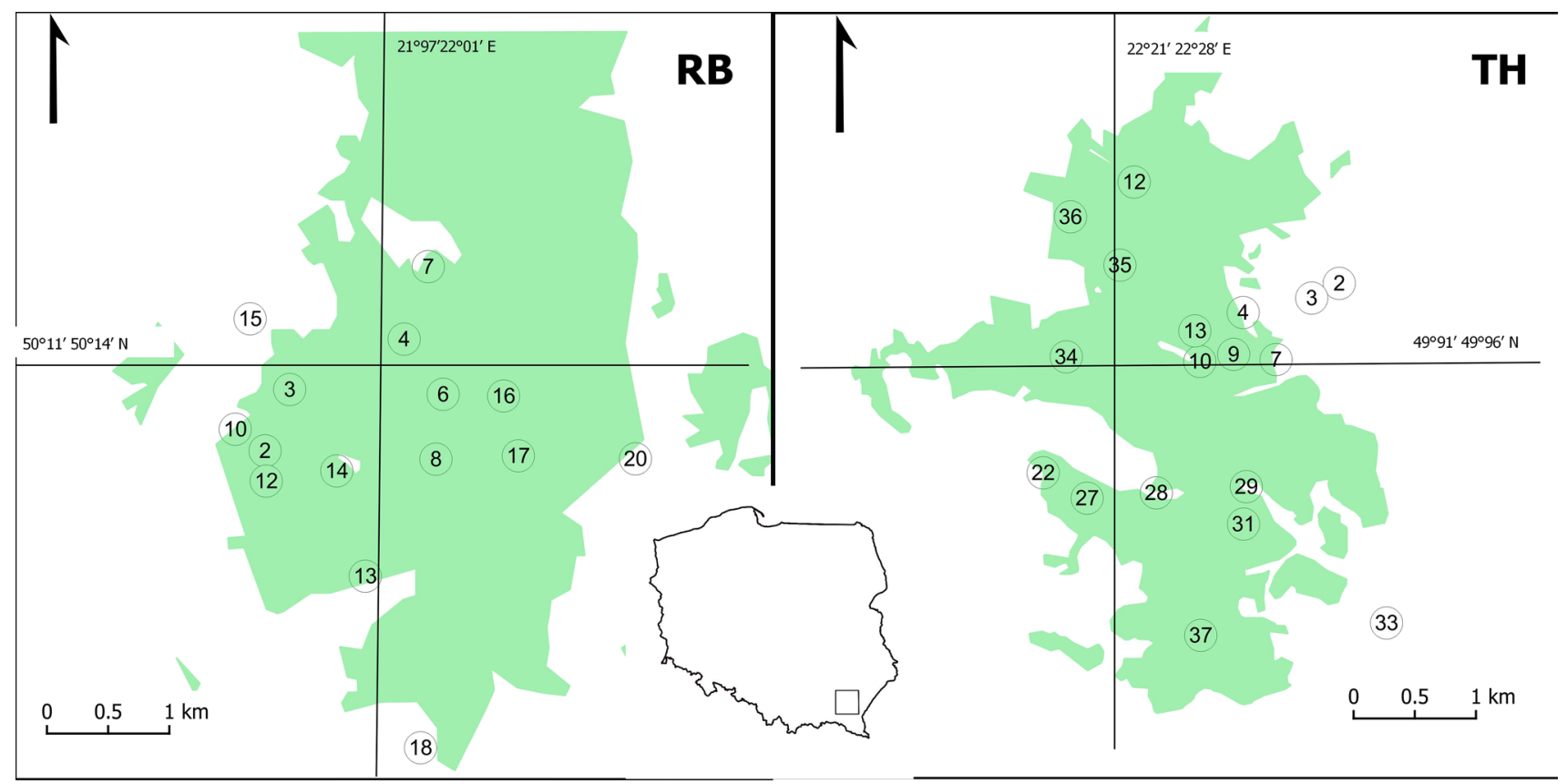

Fig. 1 Map with the location of the study area; the numbers denote the sites where moss was collected and they are consistent with the numbering presented in Tables 1,2 
Table 1 Characteristics of stands parameters of RB based on Plan Urządzania Lasu (2010)

\begin{tabular}{|c|c|c|c|c|c|c|c|}
\hline $\begin{array}{l}\text { Number } \\
\text { of sample }\end{array}$ & Location & Area (ha) & $\mathrm{SC}(\%)$ & Admixture species & Age (years) & UU (\%) & $\mathrm{H}(\mathrm{m})$ \\
\hline 2 & Under canopy & 17.72 & 90Q; 10P & $\mathrm{Q}, \mathrm{B}, \mathrm{C}, \mathrm{F}, \mathrm{Pi}, \mathrm{Po}$ & 78 & 30 & 25 \\
\hline 3 & Under canopy & 18.19 & $100 \mathrm{P}$ & $\mathrm{Q}, \mathrm{B}, \mathrm{Al}, \mathrm{PI}, \mathrm{F}$ & 88 & 50 & 25 \\
\hline 4 & Under canopy & 24.07 & $60 \mathrm{P} ; 40 \mathrm{~F}$ & Q,B,C,A & 123 & 30 & 33 \\
\hline 6 & Under canopy & 2.55 & $100 \mathrm{P}$ & $\mathrm{Q}, \mathrm{B}, \mathrm{F}, \mathrm{Pi}$ & 91 & 20 & 25 \\
\hline 12 & Under canopy & 13.32 & $100 \mathrm{P}$ & $\mathrm{Q}, \mathrm{B}, \mathrm{C}, \mathrm{F}, \mathrm{Pi}$ & 106 & 50 & 27 \\
\hline 13 & Under canopy & 12.15 & $100 \mathrm{P}$ & $\mathrm{Q}, \mathrm{Al}, \mathrm{F}$ & 96 & 20 & 25 \\
\hline 16 & Under canopy & 13.97 & $100 \mathrm{P}$ & $\mathrm{Q}, \mathrm{C}, \mathrm{Al}, \mathrm{F}$, & 83 & 50 & 26 \\
\hline 17 & Under canopy & 4.43 & 90P; 10L & $\mathrm{Q}, \mathrm{B}, \mathrm{C}$ & 29 & 20 & 13 \\
\hline 14 & Forest clearing & 5.59 & 80P; 20Q & $\mathrm{F}, \mathrm{Pi}$ & 5 & 0 & 2 \\
\hline 7 & Forest clearing & 1.72 & $100 \mathrm{P}$ & $\mathrm{Q}, \mathrm{B}, \mathrm{C}, \mathrm{F}, \mathrm{Al}$ & 69 & 30 & 23 \\
\hline 8 & Forest clearing & 5.66 & $100 \mathrm{P}$ & $\mathrm{B}, \mathrm{F}$ & 52 & 10 & 20 \\
\hline 10 & Forest edge & 1.68 & 90Q; 10P & $\mathrm{Q}, \mathrm{B}, \mathrm{C}, \mathrm{Al}, \mathrm{Pt}$ & 73 & 30 & 24 \\
\hline 20 & Forest edge & 2.28 & 90P; 10L & $\mathrm{Q}, \mathrm{F}, \mathrm{Pi}, \mathrm{T}$ & 22 & 0 & 11 \\
\hline 15 & Open area & & & & & & \\
\hline 18 & Open area & & & & & & \\
\hline
\end{tabular}

SC, tree species composition; P, Pinus sylvestris; Q, Quercus robur; F, Fagus sylvatica; L, Larix decidua; C, Carpinus betulus; B, Betula pendula; Pi, Picea excelsa; Pt, Populus tremula; Al, Alnus glutinpsa; T, Tilia cordata; A, Abies alba; Age, age of trees stands according to the dominant species; UU, undergrowth and underbrush; $\mathrm{H}$, height of trees stands according to the dominant species

Table 2 Characteristics of stands parameters of TH based on Plan Urządzania Lasu (2013)

\begin{tabular}{|c|c|c|c|c|c|c|c|}
\hline $\begin{array}{l}\text { Number of } \\
\text { sample }\end{array}$ & Location & Area (ha) & $\mathrm{SC}(\%)$ & Admixture species & Age (years) & UU (\%) & $\mathrm{H}(\mathrm{m})$ \\
\hline 12 & Under canopy & 25.45 & 40Q; 40F; 20C & $\mathrm{B}, \mathrm{P}, \mathrm{L}, \mathrm{Pt}, \mathrm{Pi}, \mathrm{Ac}$ & 97 & 30 & 26 \\
\hline 13 & Under canopy & 11.37 & 80F;10Q; 10C & $\mathrm{P}, \mathrm{B}, \mathrm{A}, \mathrm{Ac}$ & 87 & 20 & 29 \\
\hline 27 & Under canopy & 5.40 & 50F; 30A; 10Q; 10L & $\mathrm{C}, \mathrm{Ac}, \mathrm{Fr}$ & 41 & 20 & 17 \\
\hline 31 & Under canopy & 18.38 & 40C; 20F;20Q; 20B & $\mathrm{Ac}, \mathrm{Fr}$ & 93 & 80 & 25 \\
\hline 34 & Under canopy & 3.61 & 70F; 20C; 10L & $\mathrm{Q}, \mathrm{P}, \mathrm{Ac}, \mathrm{A}, \mathrm{T}$ & 85 & 30 & 25 \\
\hline 35 & Under canopy & 24.69 & 50A; 20Q; 20F; 10L & $\mathrm{C}, \mathrm{Pi}, \mathrm{Ac}, \mathrm{T}$ & 73 & 70 & 26 \\
\hline 36 & Under canopy & 3.11 & $90 \mathrm{~F} ; 10 \mathrm{~A}$ & $\mathrm{Q}, \mathrm{P}$ & 95 & 40 & 28 \\
\hline 37 & Under canopy & 20.13 & $100 \mathrm{~F}$ & $\mathrm{Q}, \mathrm{P}, \mathrm{L}, \mathrm{Pi}$ & 107 & 90 & 32 \\
\hline 9 & Forest clearing & 0.62 & & & & & \\
\hline 10 & Forest clearing & 0.62 & & & & & \\
\hline 28 & Forest clearing & 6.23 & 70A; 20Q; 10F & $\mathrm{B}, \mathrm{P}, \mathrm{C}, \mathrm{Ac}$ & 85 & 50 & 28 \\
\hline 29 & Forest clearing & 10.38 & 50F; 20L; 10C; 10Q; 10A & $\mathrm{B}, \mathrm{A}, \mathrm{Ac}$ & 43 & 20 & 16 \\
\hline 4 & Forest edge & 1.83 & $100 \mathrm{~F}$ & $\mathrm{~L}, \mathrm{Pi}$ & 33 & 0 & 13 \\
\hline 7 & Forest edge & 0.42 & Ns & & & & \\
\hline 22 & Forest edge & 10.55 & $100 \mathrm{~A}$ & $\mathrm{Q}, \mathrm{F}, \mathrm{C}, \mathrm{L}, \mathrm{Ac}$ & 87 & 30 & 31 \\
\hline 2 & Open area & & & & & & \\
\hline 3 & Open area & & & & & & \\
\hline 33 & Open area & & & & & & \\
\hline
\end{tabular}

SC, tree species composition; P, Pinus sylvestris; Q, Quercus robur; F, Fagus sylvatica; L, Larix decidua; C, Carpinus betulus; A, Abies alba; B, Betula pendula; Pi, Picea excels; Ac, Acer pseudoplatanus; Fr, Fraxinus excelsior; T, Tilia cordata; Pt, Populus tremula; Ns, natural succession; $\mathrm{UU}$, undergrowth and underbrush; $\mathrm{H}$, height of trees stands according to the dominant species

inclination, is taken into account, and this has also been positively tested in several upland and mountain forests of central Europe (Dudek 2013, 2017b). In both cases (RB and $\mathrm{TH}$ ), four auxiliary criteria were used: stand density, the presence of undergrowth and underbrush, soil cover, and stand species composition. 
Table 3 Forest recreational suitability degrees-the main assessment criteria (according to Łonkiewicz and Głuch 1991)

\begin{tabular}{llllll}
\hline Age of tree stands & \multicolumn{2}{l}{ Forest habitat types } & & \\
\cline { 2 - 6 } & $\begin{array}{l}\text { Continental } \\
\text { pine forests }\end{array}$ & $\begin{array}{l}\text { Eutrophic fresh } \\
\text { deciduous }\end{array}$ & Dry forests & Damp forests & Bog forests \\
\hline$>100$ & 4 & 4 & 3 & 1 & 0 \\
$81-100$ & 4 & 3 & 2 & 1 & 0 \\
$61-80$ & 3 & 2 & 1 & 1 & 0 \\
$41-60$ & 2 & 1 & 1 & 0 & 0 \\
$21-40$ & 1 & 1 & 0 & 0 & 0 \\
$1-20$ & 0 & 0 & 0 & 0 & 0 \\
\hline
\end{tabular}

\begin{tabular}{lll}
\hline Criterion & Basis to increase the degree & Basis to reduce the degree \\
\hline Stand species composition & Pine+deciduous & Spruce, spruce + fir \\
$\begin{array}{l}\text { Stand density } \\
\begin{array}{l}\text { Presence of undergrowth and } \\
\text { underbrush }\end{array}\end{array}$ & Loose & Full \\
Soil cover & Mosses-bilberries, bilberries & Very abundant $(\geq 40 \%)$ \\
\hline
\end{tabular}

Table 4 Auxiliary criteria for assessment of forest recreational suitability (according to Łonkiewicz and Głuch 1991)
Data on the age of the stand, the forest habitat type, terrain inclination and subsidiary criteria are required to evaluate each branch obtained from forest management plan (Plan Urządzania Lasu 2010, 2013). Habitat humidity is determined during the development of these forest management plans based on phytosociological research (indicator plants) and soil studies (soil excavation).

The advantage of the method described is the ability to analyze the measurable characteristics such as age of the forest, inclination, habitat humidity, which according Kliskey (2000) and Bulut (2018) are the most important to assess recreational utility of woodland. This method refers mainly to the protection of forests, their durability in the landscape and not to the subjective feelings of visitors and dictated desire to visit a given area. Therefore, the humidity of the habitat is more important than surface waters because this parameter, along with the inclination of the area and the age of stands, determines potential recreational and tourist damage in the forests.

Given the above, according to the authors selected methodological approach is best suited to achieving the aim set out in this paper, where research areas are in the forests of central Europe exposed to recreational damage.

Recreational carrying capacity (RCC) is calculated as the product of the degree of forest stand recreational suitability and the area of forest stands belonging to a particular degree. Next, the mean forest recreational capacity was calculated as the quotient of the recreational capacity of the study area and the total area of forest stands in the study area (man-hour $\times \mathrm{ha}^{-1} \times$ day $^{-1}$ ).

This method takes into account the most popular forest recreation forms, i.e., walking, running, Nordic walking, and cycling. But it does not include extreme leisure forms such as climbing, MTB (mountain terrain bike), freestyle skiing, etc., where a large slope inclination is desired. The classification of recreational suitability of forest stands uses a 5-point scale (Lonkiewicz and Gluch 1991):

4-forest stands of very high suitability;

3 - forest stands of high suitability;

2-forest stands of medium suitability;

1 -forest stands of low suitability;

0 - unsuitable forest stands.

Depending on the mean terrain gradient for a forest unit, the following assignment of a forest stand to the respective degree of recreational suitability was adopted (Dudek 2013):

degree 0 - precipitous slope (more than $45^{\circ}$ );

degree 1 -lowland area, very steep slope $\left(31^{\circ}-45^{\circ}\right)$;

degree 2 -steep slope $\left(18^{\circ}-30^{\circ}\right)$;

degree 3 -mild slope (up to $7^{\circ}$ ), strongly inclined slope $\left(13^{\circ}-17^{\circ}\right)$,

degree $4-$ slanted slope $\left(8^{\circ}-12^{\circ}\right)$.

Performing the assessment in the plain area $(\mathrm{RB})$, the age class of the stand within the group of forest habitat types decides about the allocation of the forestry division to the level of recreational suitability. In the terrain with diversified relief $(\mathrm{TH})$ one should observe the principle that the lower value of two assessed main criteria (age of forest stand and inclination) within the forest habitat group determines the allocation of forestry division to the level of recreational suitability. 


\section{Pollen deposition analysis}

The palynological research methodology followed the recommendations of the Pollen Monitoring Programme (http:// www.pollentrapping.net/). Clump of moss with a diameter of $5 \mathrm{~cm}$ were pollen traps. Although the collection of moss samples was carried out once at the end 2012, the spectrum of pollen isolated from this type of traps reflects severalyear-long deposition and such information is necessary to achieve the defined aim of the study. Moss was collected in the forest at places with a dense stand structure (under the canopy), in forest clearings, and at the forest edge. Moreover, moss was also collected in an open area where the distance from the forest edge was at least $500 \mathrm{~m}$. The field-collected moss samples were stored in a fridge at -7 to $-8{ }^{\circ} \mathrm{C}$.

The field-collected moss was placed in a boiling water bath in a $3.5 \% \mathrm{KOH}$ solution for $10 \mathrm{~min}$ in order to separate pollen grains from the moss. After washing it with distilled water, the material was filtered through sieves with decreasing mesh sizes and subsequently the filtered water was centrifuged and then decanted. A solution with 5 dissolved Lycopodium marker tablets was added to the sediment. The centrifuged sediment was washed with glacial acetic acid and after the sediment was centrifuged again, acetolysis mixture was poured over it: 9 parts of acetic anhydride and 1 part of concentrated sulfuric acid. The centrifuged sediment was immersed in alcohol with the following ratio: 1 part of water and 3 parts of alcohol, and after centrifugation several drops of fuchsin-stained glycerol were added. At each stage, the centrifugation lasted $3 \mathrm{~min}$ at 4500 revolutions/min. For each sample, microscopic slides were prepared and analyzed at a magnification of 400 , counting at least 500 pollen grains and at least 100 Lycopodium spores (Pidek 2007). The results were converted according to the following formula:

Pollen influx $=[$ (number of added Lycopodium spores $/$ number of counted Lycopodium spores) $\times$ number of counted pollen grains of a given taxon]/moss diameter.

Most pollen grains were identified to genus level, rarely to family like Poaceae or Amarathaceae or to type like Plantago major/minor type. Each pollen taxon was also specified as AP (arboreal pollen) or NAP (non-arboreal pollen).

\section{Data analysis}

The calculation of the potential allergenicity and actual allergenicity of forest stands was partly based on the formula developed by Cariñanos et al. (2014).

The actual impact of forest stand vegetation (forest impact- FI) on humans was assessed based on the value of
PI (pollen influx) of a given taxa, potential allergenicity of its pollen $(a p)$ in a 1-4 scale, duration of pollination period of a given taxa in a 1-3 scale ( $p p)$, and pollination strategy (ps; self-fertilized, entomophilous, amphiphilous, anemophilous) according to a $0-3$ scale. The higher the values of the above-mentioned parameters, the stronger negative impact on humans. The detailed description relating these parameters are presented by Cariñanos et al. (2016).

$F I=\sum_{i=1}(\mathrm{ap} i * \mathrm{pp} i * \mathrm{ps} i * \mathrm{PI} i)$

The values of pollen index (PI) of some taxa were high; hence, often the FI values were several hundred thousand. To better follow the text, the values of FI are expressed in exponential form, always $10^{5}$. The higher the FI value, the more negative the impact of the forest is.

The potential impact of forest stand vegetation (PFI) was determined based on the mean proportion of the area occupied by the tree species (TS). Based on data presented in the Tables 1, 2 for each species, the average percentage share in the forest was calculated. Maximum value of PFI is 36 .

$\mathrm{PFI}=\sum_{i=1}(\mathrm{ap} i * \mathrm{pp} i * \mathrm{ps} i * \overline{\mathrm{TS}} i)$

For each site type, the mean value of FI was calculated and then statistically significant differences were detected using one-way ANOVA test, having first checked for normal distribution using the Shapiro-Wilk test and for the homogeneity of variance by the Brown-Forsythe test. Detailed pairwise comparisons were done using LSD test (Least Significant Difference). The statistical hypotheses were tested at $\alpha \leq 0.05$, and all calculations were carried out with Statistica 10.0 software package.

Contributions of pollen taxa to the FI value of different site types (under the canopy- $-\mathbf{u c}$, forest clearings- $\mathbf{f c}$, forest edge-fe, open area-op) were examined through a multidimensional Principal Component Analysis (PCA) using Canoco 5software. The results were illustrated in the two-dimensional plot, where the site types were presented as arrows and pollen taxa as dots.

Due to the fact that the forest impact (FI) and the recreational carrying capacity (RCC) indicators are expressed in different units they cannot be compared directly. Therefore, their values were transformed into $Z$-values.

$Z=\left(x_{1}-\mu\right) / \sigma$

where $\sigma$ is the standard deviation of the population, and $\mu$ the mean of the population.

Standardization converts a variable with unit into a variable without unit. After that the additivity and range stability postulates were fulfilled and the indicators (FI and RCC) could be directly compared looking at the sign and the value of $z$-variables. Raw values above the mean have 
positive $\mathrm{z}$-variables, while values below the mean have negative $\mathrm{z}$-variables.

\section{Results}

\section{Recreational potential of the studied forests}

The RB forests are diverse. Eutrophic fresh deciduous are most numerous (36.64\% of the total area), and they show high suitability for recreational use. Continental pine forests, in which there are forest stands of the highest recreational suitability, occupy $33.73 \%$ of the area. Damp forests of low recreational suitability account for the remaining $29.63 \%$. In the case of $\mathrm{TH}$, on the other hand, the upland fresh eutrophic accounts for $100 \%$ of forest stands (Tables 1,2).

The forest stand age structure looks beneficial for recreation; the older a forest stand is, the more suitable for recreation it is. Forest stands in age class VI and older ( $>100$ years) cover $30.32 \%$ of the RB area and $14.26 \%$ in $\mathrm{TH}$; as regards the other age classes: $\mathrm{V}-38.00 \% \mathrm{RB}$ and $55.76 \% \mathrm{TH}$; class IV-17.12\% RB and $17.49 \% \mathrm{TH}$; class III- $4.59 \% \mathrm{RB}$ and $11.18 \% \mathrm{TH}$; class II- $5.44 \% \mathrm{RB}$ and $1.30 \%$ TH. Nurseries and young-growth stands excluded from recreational use (age class I-up to 20 years of age) occupy only $4.53 \%$ of the RB area, while in $\mathrm{TH}$ none were found. Upland forests occupy $100 \%$ of the $\mathrm{TH}$ area, whereas in RB they do not occur (Tables 1,2). A large majority of upland forests in $\mathrm{TH}$ grow on slopes with an inclination of $8^{\circ}-12^{\circ}(87.76 \%)$, which is the most beneficial in terms of the possibility of forest recreational use (Dudek 2013). The other ones grow on slopes with an inclination of $7^{\circ}$ or $13^{\circ}-17^{\circ}$.

Forest stands suitable for recreational use account for $67 \%$ of the area of the evaluated forests in RB and $87 \%$ in TH (Table 5, degrees 2-4). Forest stands of low suitability or

Table 5 Recreation carrying capacity (RCC) of the forests in the studied areas

\begin{tabular}{lllllll}
\hline $\begin{array}{l}\text { Level of recreational usefulness of } \\
\text { forest stands }\end{array}$ & $\begin{array}{l}\text { Area of forest } \\
\text { stands (ha) }\end{array}$ & $\begin{array}{l}\text { Recreation car- } \\
\text { rying capacity } \\
\text { (RCC) (man- } \\
\text { hour/day) }\end{array}$ \\
\cline { 2 - 3 } & RB & TH & & RB & TH \\
\hline 4 & 24.07 & 0.00 & 96.28 & 0.00 \\
3 & 54.89 & 117.29 & 164.67 & 351.87 \\
1 & 3.40 & 6.23 & 6.80 & 12.46 \\
0 & 14.70 & 15.78 & 14.70 & 15.78 \\
Total & 26.27 & 1.83 & 0.00 & 0.00 \\
Average (man-hour $\times \mathrm{day}^{-1} \times \mathrm{ha}^{-1}$ ) & 123.30 & 141.13 & 282.45 & 380.11 \\
\hline & & & & 2.29 & 2.69 \\
\hline
\end{tabular}

unsuitable stands occupy $33 \%$ of the RB area and $13 \%$ in $\mathrm{TH}$ (Table 5, degrees 0 and 1). A reduction in the degree of recreational suitability of forest stands primarily resulted from the presence of dense underbrush (one of the 4 supplementary criteria). The calculated forest recreational capacity was 282.45 man-hour $\times$ day $^{-1}$ in RB and 380.11 in TH, which gives the mean recreational capacity equal to, respectively, 2.29 and 2.69 man-hour $\times$ day $^{-1} \times$ ha $^{-1}$ (Table 5).

\section{Pollen analysis}

Pollen deposition clearly differed between forests and site types. In RB the mean PI value was 100104.0, while in TH it was nearly twice less (PI=58387.7). In both forests, the under-canopy sites were characterized by the lowest PI value. In $\mathrm{RB}$, on mean the highest amount of pollen was found in the samples collected at the forest-edge sites, whereas in $\mathrm{TH}$ in the open-area locations. In both forests, arboreal pollen was dominant in all site types. In RB, the lowest amount of arboreal pollen was found outside the forest, whereas in $\mathrm{TH}$ the mean PI value for trees was highest in this type of sites. Although in TH the PI values were distinctly lower than those for $\mathrm{RB}$, the percentage ratios between AP and NAP, except for the forest-edge locations, were very similar, that is, the greatest disproportions between the PI values for these two groups were found in the under-canopy samples. At these sites, arboreal pollen accounted for as much as $3 / 4$ (Fig. 2).

The tree species diversity of the forests was lower than the diversity of the tree pollen grains identified. In the RB forest stands, $P$. silvestris was the dominant species and a maximum of 6 tree species were found in the admixture

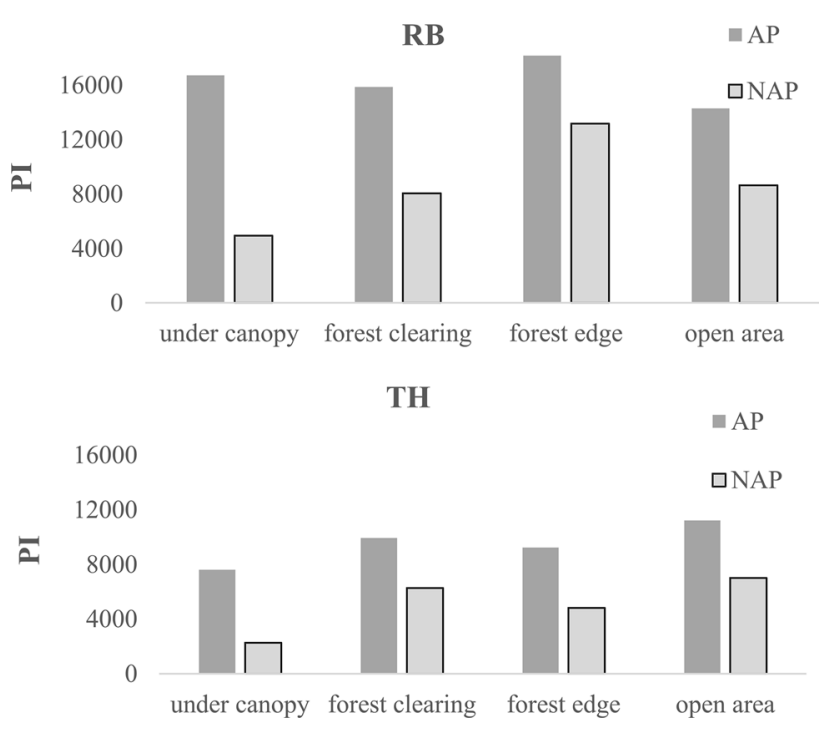

Fig. 2 Values of pollen influx (PI) for arboreal pollen (AP) and nonarboreal pollen (NAP) 
(Table 1), whereas the pollen of as many as 23 woody taxa was found in the deposition, out of which 6 were recorded sporadically. In $\mathrm{TH}$, there were more dominant species than in RB, in some forest units up to 5 species, whereas in the admixture from 2 to 5 species (Table 2). Pollen of 18 arboreal taxa was found in the deposition. Forest stand composition (Tables 1,2) is not reflected in the quantitative and qualitative spectrum of arboreal pollen deposition. Regardless of the forest or site type, in each moss sample Pinus pollen was predominant (Fig. 3). In RB it accounted for 70 to $78 \%$ and its mean percentage in the stand was estimated at $76 \%$. In the samples collected in $\mathrm{TH}$, there is an overrepresentation of Pinus pollen. P. silvestris occur in a few stands but only as the admixture species, but its pollen content in the deposition ranged from 42 to $47 \%$. The nearest larger clusters of pine occur about $3 \mathrm{~km}$ from the forest. Underestimation of pollen in the moss traps applies to Abies, Fagus, Carpinus, and Quercus. It was not rare that high PI values were noted in the deposition for several taxa, whereas in the forest stand their percentage was very small (Fig. 3; Tables 1, 2). It related, among others, to Betula pollen which was found in large amounts in the moss samples from the RB and $\mathrm{TH}$ forests, accounting, respectively, for 9 to $13 \%$ and from 17 to $26 \%$, while in the forest stands B. pendula did not occur or occurred rarely. In RB A. glutinosa and C. betulus were an admixture, but their pollen was found in the moss traps collected at each site type. The opposite relationship was found in the case of Larix. The percentage of its pollen in the deposition was insignificant (in total, only several pollen grains were found), whereas the mean percentage of
L. decidua in the $\mathrm{TH}$ forest stands was estimated at nearly 4\% (Fig. 3).

The taxonomic richness of herbaceous pollen found in the moss traps was greater than in the case of tree pollen. In BR 42 taxa were identified, but only in the case of six of them their pollen grains were found in most of the samples. In $\mathrm{TH}$ 23 taxa were identified, but the PI values were considerable only for six of them, mostly the same as in RB. Regardless of the forest and site type, Poaceae pollen was dominant in the NAP group. In TH its PI values were comparable to Pinus. As regards the herbaceous group, Urtica, Rumex and Plantago lanceolata pollen grains were found in each sample from each forest stand.

\section{Forest stands and the risks to people}

The palynological analysis allowed us to determine the actual effect strength of allergenic pollen originating from the forest on humans (FI). The number of pollen grains deposited in moss pollsters is a proxy of total pollen production per a given plant community, here forest. In both forest types, apart from arboreal pollen, pollen grains of herbaceous plants were found in large numbers and their percentage was significant-about $33 \%$. They include Poaceae pollen, which are a source of very strong allergens and its allergenicity potential has a maximum value, i.e., 4 , as well as the pollen of Rumex and P. lanceolata, for which allergenicity potential is 3 . It was demonstrated that people visiting the RB forest would be more exposed to the effect of aeroallergens than in $\mathrm{TH}$, which was confirmed
Fig. 3 Percentages of dominant tree species in $\mathrm{RB}$ and $\mathrm{TH}$ forest stands and of pollen grains isolated from the moss originating from 5 site types

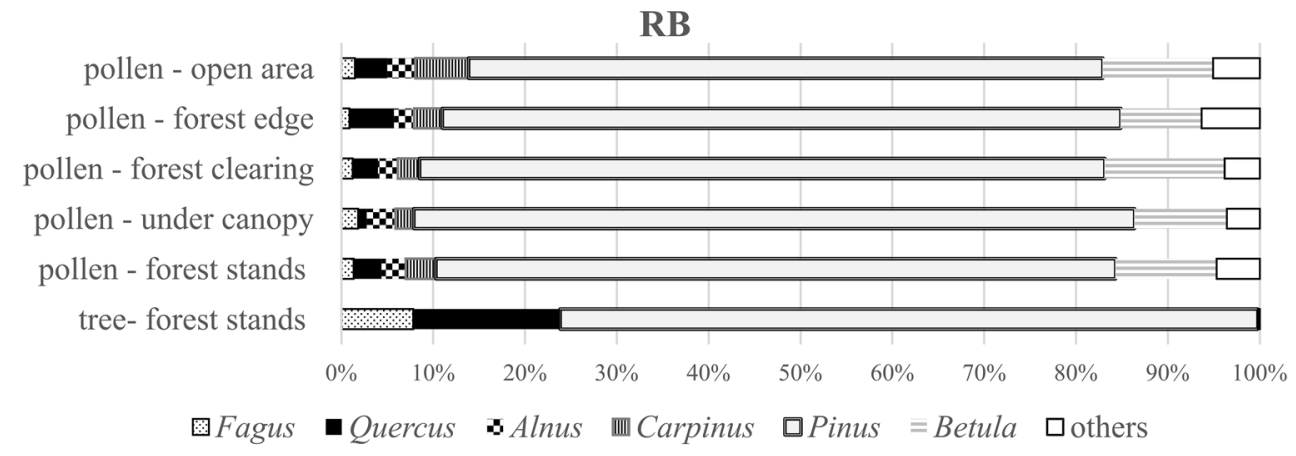

TH

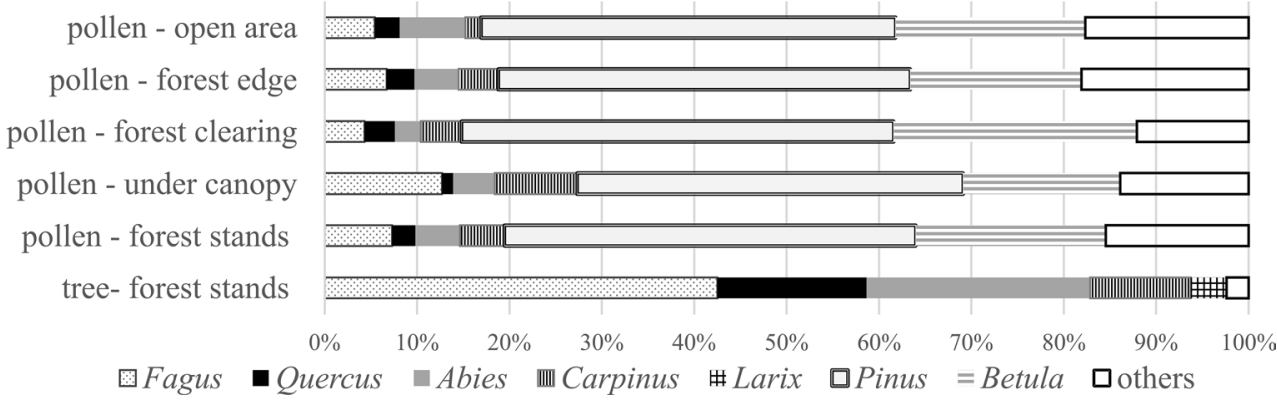


by relevant calculations (see Forest Impact formula). The mean FI values are $5.25 \times 10^{5}$ and $3.52 \times 10^{5}$, respectively. The forest impact depends on the place that one is visiting. In both forest types, under-canopy sites are places with the weakest effect of aeroallergens, whereas the forest-edge and open-area sites pose the greatest risk (Fig. 4). The mean FI values for the under-canopy sites in BR and TH were $3.93 \times 10^{5}$ and $2.17 \times 10^{5}$, respectively, and differed significantly from the other site types. In RB the forest-edge site was characterized by the highest mean FI $\left(\mathrm{FI}=7.07 \times 10^{5}\right)$, which significantly differed from the mean FI values of the under-canopy and the forest clearing sites $(\mathrm{F}=6.974$; $p=0.008178$ ). In contrast, in TH the mean FI value of the open-area site has the highest FI value $\left(\mathrm{FI}=4.48 \times 10^{5}\right)$ was significantly differed from those of under-canopy and forestedge sites. $(\mathrm{F}=18.003 ; p=0.000045)$.

The potential risk to people from forest aeroallergens differs depending on the forest type and in consequence of percentage of forest area occupied by dominant tree species. The Central European submountainous beech forest (TH)
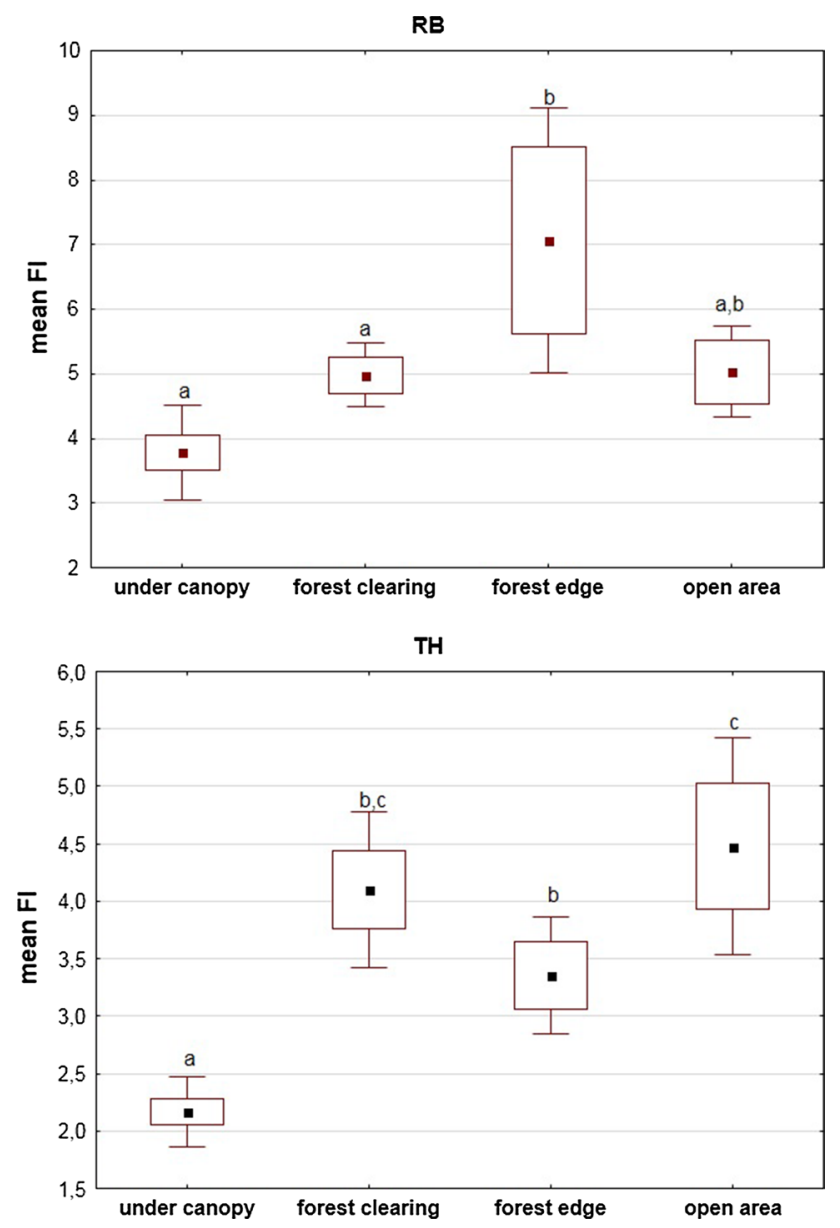

Fig. 4 Mean values of FI index for different site types in RB and TH forest stands. Arabic letters mean humongous groups distinguished on the base of LSD post hoc test is characterized by a larger number of tree species whose pollen exhibits high or relatively high allergenic potential (ap) and such species include $C$. betulus, $Q$. robur, and $F$. sylvatica. The percentage contribution of these species to the TH forest is close to 70\%, while the PFI value is 14.8 . The RB forest (Nemoral Scots pine forest) was dominated by $P$. sylvestris whose $a p$ is rated only at $1 . Q$. robur occupies between 10 and $20 \%$ of the area, while F. sylvatica up to $5 \%$. On this basis, it was found that the potential negative impact of beech forest aeroallergens on humans is higher than in the case of the pine forest, for which $\mathrm{PFI}=12.1$.

The PCA biplots demonstrated which of pollen taxa had the greatest influence on the FI value (Figs. 5,6). For RB and $\mathrm{TH}$, two axes of PCA explained $96.87 \%$ and $94.92 \%$ of variances, respectively. As the biplots showed, the mean values of FI of RB and TH depended on different pollen taxa (Figs. 5,6). In BR forest, the under-canopy site was clearly different from the others sites and its value of FI depended on P. lanceolata, Pinus, Betula, Alnus and Carpinus pollen. The pollen of most herbaceous plants is of no importance. In contrast, in $\mathrm{TH}$, under canopy and on the forest clearings the adverse impact of pollen on humans depended on Fagus, Carpinus and Corylus pollen. In the forest-edge and openarea sites, the values of the FI are affected by Poaceae, Pinus and Betula pollen.

Figure 7 shows the comparison among the FI and RCC values. In both forests, at under-canopy sites the importance of these indicators is adverse. These places are conducive to man, because the recreational capacity is the largest and the negative effect of pollen is the smallest. The reverse was

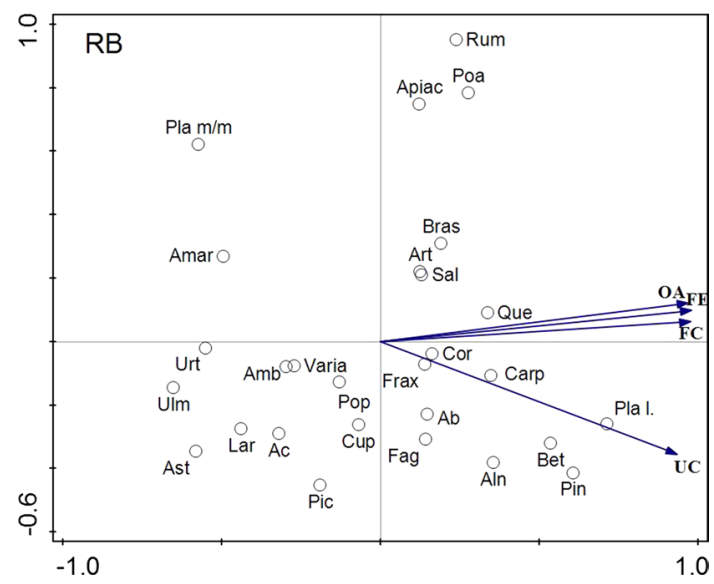

Fig. 5 PCA biplots illustrating the contributions of pollen taxa to the FI value of different site types (under the canopy-uc, forest clearings- $\mathbf{f c}$, forest edge- $\mathbf{f e}$, open area-op) in RB. Ab, Abies; Ac, Acer; Aln, Alnus; Amar, Amaranthaceae; Amb, Ambrosia; Apiac, Apiaceae; Ast, Asteracea; Bet, Betula; Bras, Brassicaceae; Carp, Carpinus; Cor, Corylus; Cup, Cupresseaceae; Fag, Fagus; Frax, Fraxinus; Lar, Larix; Pic, Picea; Pin, Pinus; Pla 1., Plantago lanceolata; Pla m/m, P. major/media; Poa, Poaceae; Pop, Populus; Que, Quercus; Rum, Rumex; Ulm, Ulmus; Urt, Urtica 


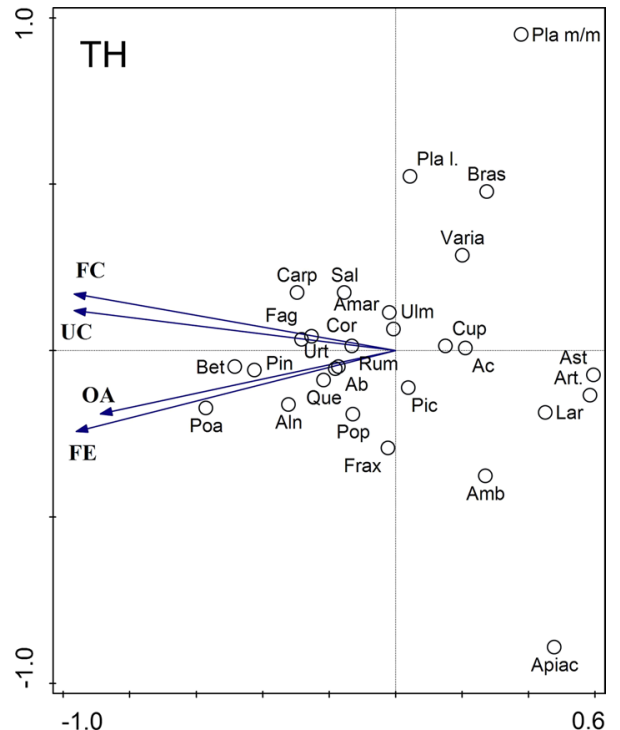

Fig. 6 PCA biplots illustrating the contributions of pollen taxa to the FI value of different site types (under the canopy- uc, forest clearings - fc, forest edge- $\mathbf{f e}$, open area-op) in $\mathrm{TH}$. Ab, Abies; Ac, Acer; Aln, Alnus; Amar, Amaranthaceae; Amb, Ambrosia; Apiac, Apiaceae; Ast, Asteracea; Bet, Betula; Bras, Brassicaceae; Carp, Carpinus; Cor, Corylus; Cup, Cupresseaceae; Fag, Fagus; Frax, Fraxinus; Lar, Larix; Pic, Picea; Pin, Pinus; Pla 1., Plantago lanceolata; Pla m/m, P. major/media; Poa, Poaceae; Pop, Populus; Que, Quercus; Rum, Rumex; Ulm, Ulmus; Urt, Urtica
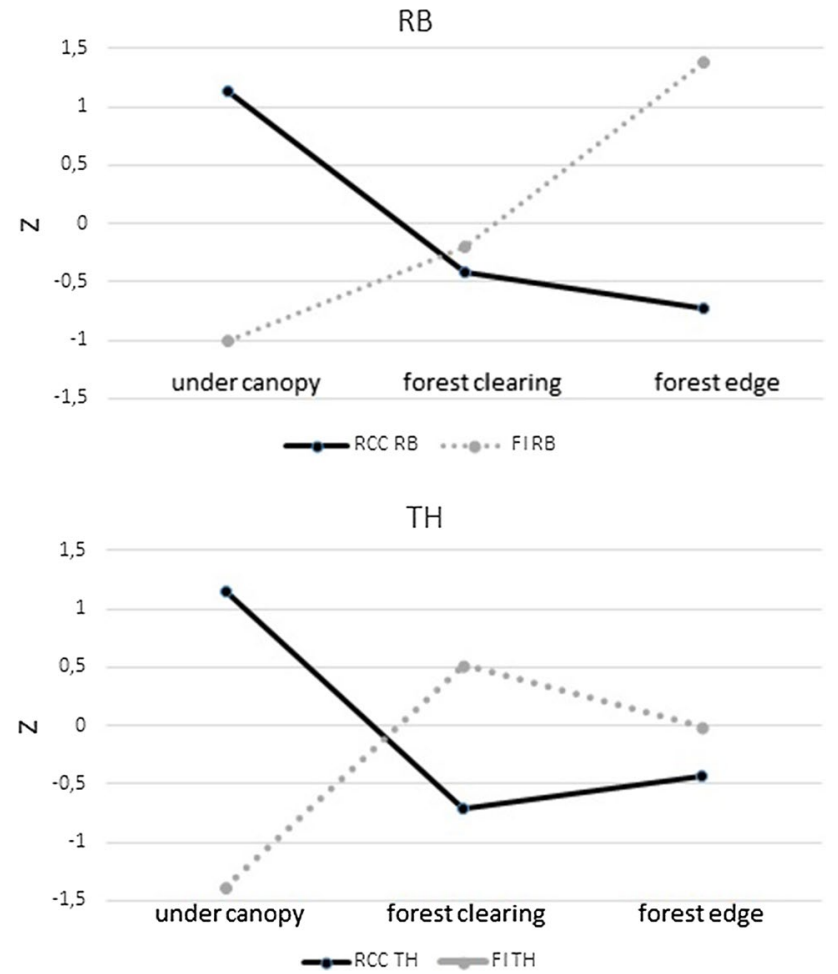

Fig. $7 \mathrm{Z}$ values of RCC (recreational carrying capacity) and FI (forest impact) indicators for under-canopy, forest clearing and forest-edge sites in $\mathrm{RB}$ and $\mathrm{TH}$ forest stands at open area in RB and in forest clearing in TH. There was no relationship between the potential and real impact of the studies forest stands on humans. To sum up, TH (beech forest) is characterized by greater recreational potential as expressed by higher recreational capacity and the weaker actual effect of aeroallergens than in the case of RB (pine forest; Fig. 8).

\section{Discussion}

In times when allergies have become a social disease, the negative effect of vegetation on human health and wellbeing, i.e., environmental disservices, is gradually being noticed. Despite that the level of knowledge on the adverse effect of plant pollen on humans is increasingly higher, research is focused on urban greenery (Andrusaityte et al. 2016; Cariñanos et al. 2016, 2017), but it neglects natural ecosystems. Andrusaityte et al. (2016) demonstrated that the risk of asthma is growing among 4-6-year-olds living within $100 \mathrm{~m}$ from large urban green areas. In the case of natural habitats, mainly benefits are noticed (Annerstedt et al. 2010; Hansen et al. 2017), but their negative effects are rarely mentioned (van den Bosch 2017). Some researchers noticed such risk posed by forests with a predominance of Japanese cedar producing very strong allergenic pollen (Morita et al. 2009), but they did not present any detailed quantitative analysis. It is difficult to accurately determine pollen production by plant communities and, consequently, the scale of their negative effects, but palynological research provides some possibilities. It allows us to determine the scale of threat and to indicate which natural habitats pose high risk to allergic people. So far, such research has not been conducted for natural communities-forests, and therefore our study fills the gap in the literature of the subject.

The obtained results provide information on the risk of health worsening among allergy sufferers visiting forest areas or their immediate vicinity. The quantitative and qualitative spectrum of pollen deposition is characterized

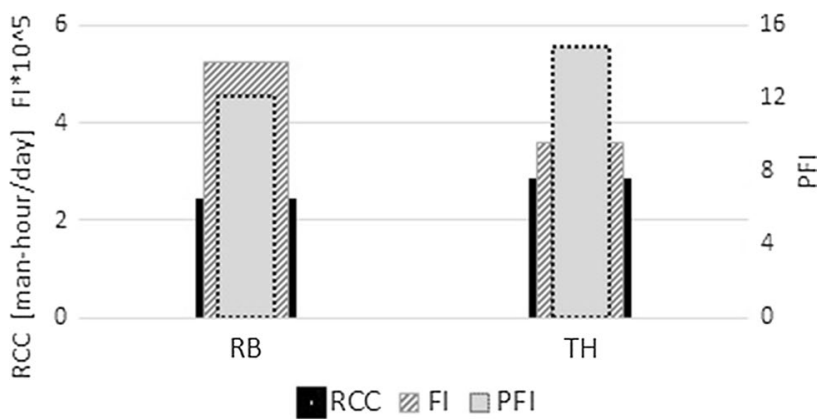

Fig. 8 The comparison between RCC (recreational carrying capacity), FI (forest impact) and PFI (potential forest impact) indicators in $\mathrm{RB}$ and $\mathrm{TH}$ forest stands 
by significant spatial variation, even within a small area, as proven by numerous palynological studies (Poska and Pidek 2010; Baker et al. 2016). These differences arise not only from variations in in situ vegetation but also in regional vegetation. Our study has confirmed these reports. The pollen deposition in the forest and its vicinity varies in each of the forest areas studied. Both in the beech forest $(\mathrm{TH})$ and in the pine forest (RB), under-canopy locations are places of the weakest impact of aeroallergens, forestclearing and forest-edge sites pose greater risk, while the greatest risk is found at open-area sites. These results are seemingly surprising but, as reported by many authors, the pollen deposition spectrum is not an accurate reflection of vegetation. Even the presence of airborne pollen depends on very many factors. They include those associated with the abundance of pollen production and those related to the structure of pollen grains and their dispersal ability (Subba Reddi and Reddi 1986; Piotrowska 2008). Heavier pollen grains of the fir, larch, maple and beech remain in the air for a very short period of time (Broström 2002; Poska and Pidek 2010). Due to this fact and low pollen production, the percentage of larch pollen in the deposition is minimal, though in several forest units in TH it was a significant species. The pollen of this taxon, just like maple and spruce, has no effect on the FI value in both stands. An opposite phenomenon was noted in the case of $P$. sylvestris. Poska and Pidek (2010) report that trees located at a distance of even $4500 \mathrm{~m}$ from the place where the pollen deposition was investigated had a noticeable effect on the pollen loading value. Similarly as in the case of Pinus, Betula, pollen grains have a larger dispersal area due to their high production and good dispersal ability (Subba Reddi and Reddi 1986; Skjøth et al. 2008) than pollen grains of other species present in the forest stands; therefore, they were found in each sample with a high frequency, even in the samples taken in the forest units where no trees grew as well as in those collected in the open-area locations. This is confirmed by PCA analysis indicating that in TH pollen of these two taxa as well as Poaceae has the largest contribution to the high FI value of open area sites. Why are we less exposed to contact with an aeroallergen in the forest than in its vicinity? The number of pollen grains produced by a stand-alone (solitary) tree is higher than that produced by trees in a dense stand (Aaby 1994). Moreover, in trees growing at high density, inflorescences occur in greater numbers in the upper parts of the crown. Pollen released in the upper parts of the tree crown is more prone to horizontal winds and transport for a dozen or several dozen kilometers (Kuparinen et al. 2007). This explains the higher arboreal pollen concentrations outside the forest. In the middle and lower parts of the crown, the number of inflorescences is lower than at the crown top, and trees growing under the canopy do not flower almost at all (Milleron et al. 2012). It does not mean that there is no risk from allergenic pollen. Underbrush and forest floor are also its source. Pollen released at nose height, e.g., by hazel trees that produce very large amounts of allergenic pollen, can also pose a risk to forest visitors (Piotrowska 2008).

Information on the risk of allergenic pollen in natural communities would be extremely useful in controlling recreational traffic since, as we have proved, visiting appropriate places in the forest allows the exposure of allergen sensitive people to be reduced. A study conducted by Dudek (2017a) concerning preferences of residents of the region where the present study was carried out reveals that people most willingly spend their leisure time in the forest interior (36\% of respondents). However, a comparable number of respondents choose for recreation places where pollen concentrations are higher: the forest-edge zone (18\% of respondents) and forest clearings (17\% of respondents). Similar results are presented by Gołos (2013), according to whom $43 \%$ of the surveyed residents of the capital city declared that they choose the forest interior as the place for recreation, while $25 \%$ the forest-edge zone. In another study, on the other hand, as many as $57 \%$ of Warsaw residents declared that they choose to spend their leisure time in the forest-edge zone and only $12 \%$ in the forest interior (Janeczko and Woźnicka 2009). As shown by de Meo et al. (2015), forest visitors' preferences are associated with the forest structure. Visitors to the Italian Alps prefer more open forests (82\% of respondents), with a lower crown density, than closed forests (18\% of respondents). The obtained results regarding the risk of allergenic plant pollen in different places of the forest, with an appropriate level of education as regards the need to use prevention in allergic diseases, can completely reshape forest visitors' preferences with respect to the places of recreation (forest interior, edge zone, forest clearings). They can also be important information for forest managers in the situation when, on the one hand, we need to take into account the growing interest in forest recreation, while on the other hand, the increasing number of allergy sufferers. Morita et al. (2009) indicate the need to inform the society, through public advertisements, about the risk of exposure to pollen during forest visits in the course of the plant pollination season. The purpose of such information campaigns conducted in Japan is to increase the percentage of people aware of the existing risks to allergy sufferers. Although most of the respondents (65.2\%) still visit forests even during the pollen season, $28.6 \%$ of the Japanese people surveyed declare that they avoid visiting forested areas during the pollen season (Morita et al. 2009).

The recreational suitability of forest communities depends on forest age, habitat resistance to recreational damage (soil treading, destruction of forest floor vegetation, damage to young trees), forest type (deciduous, 
coniferous, mixed), young-growth density, forest floor species composition, crown density, and microclimate (Dudek 2013; Kikulski 2006). The value of the recreational capacity indicators exceeded 2.2 man-hour $\times$ day $^{-1} \times \mathrm{ha}^{-1}$ what was higher than indicator calculated for suburban forests of the city of Rzeszów located within a distance of up to $20 \mathrm{~km}$ from its boundaries, where this value was 1.79 manhour $\times$ day $^{-1} \times$ ha $^{-1}$ (Dudek 2016). They are also higher relative to the 4 Carpathian (mountainous) forest national parks where the calculated mean recreational capacity was from 1.93 to 2.11 man-hour $\times$ day $^{-1} \times$ ha $^{-1}$ (Dudek 2017b). Thus far, assessments of forest recreational suitability have not taken into consideration the needs of people suffering from pollen allergies. This study, conducted in two forest types commonly found in the temperate climate zone, i.e., Central European submountainous beech forest and Nemoral Scots pine forest, shows that the potential forest impact (PFI) of the beech forest is higher than that of the pine forest. Thus, if only the species composition of dendroflora is taken into account, it would seem that the pine forest is a better place for recreation for allergy sufferers than the beech forest. Nevertheless, palynological studies have not confirmed this. A forest visitor is exposed not only to the pollen of trees growing in the forest, but also to high concentrations of herbaceous pollen. The forest impact depends, among others, on the allergenic potential of plants growing in the forest, the amount of pollen production, pollen frequency not only in the forest, but also in the forest's vicinity because pollen transport to the forest cannot be excluded. Although beech pollen is characterized by higher allergenic potential than pine pollen, its production is much smaller than in the case of other deciduous trees or the pine, but the beech pollen season is relatively short (Subba Reddi and Reddi 1986; Cariñanos et al. 2016). In mixed and pine forests, pollen concentrations, in particular the concentration of pine pollen, but also of strongly allergenic birch, hornbeam and oak pollen, are much higher and therefore, as a matter of fact, the beech forest exhibits a weaker actual impact of aeroallergens than the pine forest. Therefore, in order to assess the strength of the influence of forest on people, it is not enough to analyze its composition, but it is necessary to study the spectrum of pollen fall. In assessing the recreational potential of a forest, its type should form the basis for modification of the degree of recreational suitability. In the light of the obtained results, a pine stand with an admixture of deciduous species, including birch to a large extent, which is exactly the forest stand type that we find in RB, is the basis for reducing the degree of recreational suitability. A number of studies reveal that people prefer mixed forests for recreation (Nielsen et al. 2007; Grilli et al. 2014), they are followed by evergreen forests, while broadleaf forests are least preferred (de Meo et al. 2015). There is also an opinion that tree species only slightly affect forest recreational suitability
(Edwards et al. 2012), though it is thought that coniferous species affect it to the least extent. Forest structure seems to be more important. Thus, the situation is complex because, on the one hand, people prefer mixed and coniferous forests for recreation and they are rated higher in determining forest recreational potential. On the other hand, as shown by our results, this type of forest is characterized by a greater actual impact of aeroallergens than the deciduous beech forest. Our finding is particularly important in the light of other data that show that the coniferous forest, due to its microclimate, has antiseptic, anti-tuberculosis, and antiasthmatic properties (Krzymowska-Kostrowicka 1997).

\section{Conclusions}

We have shown that assessment of forest recreational suitability requires us to take into account the risk to forest visitors arising from the emission and dispersal of allergenic plant pollen. It is a novelty in this type of research because so far this problem has not been noticed. The initiated direction of research is particularly important at a time when the scale of allergy incidence is growing. We think that a good understanding of this problem requires cooperation of not only the forester and the aerobiologist, but also experts from epidemiology, public health, botany, ecology, and geography. At this stage of research, the obtained results can form a certain basis for developing new principles for assessment of suitability of forests for recreational use.

Despite that the present research was a pilot study, we can present certain recommendations for forest visitors. When planning outdoor recreation in a highly forested area, one should keep in mind that we are less exposed to the impact of pollen in the forest itself than in the close vicinity to the forest. It is essential to know flowering times of the most important allergenic plants. Recreation in beech forests is the most dangerous in early spring, late summer and autumn, while as far as coniferous or mixed forests are concerned, the period when they can be safely visited is shorter. In this type of forest, the best time for recreation during the growing season is early spring and the period until late summer. Nevertheless, these times are dependent on the geobotanical or climatic region and hence it is necessary to know the pollen calendar. As stressed by the World Allergy Organization (Pawankar et al. 2013), avoiding contact with allergens is more important than pharmacological treatment.

Open Access This article is distributed under the terms of the Creative Commons Attribution 4.0 International License (http://creativeco mmons.org/licenses/by/4.0/), which permits unrestricted use, distribution, and reproduction in any medium, provided you give appropriate credit to the original author(s) and the source, provide a link to the Creative Commons license, and indicate if changes were made. 


\section{References}

Aaby B (1994) NAP percentages as an expression of cleared areas. Paläoklimaforschung 12:13-27

Andrusaityte S, Grazuleviciene R, Kudzyte J, Bernotiene A, Dedele A, Nieuwenhuijsen MJ (2016) Associations between neighborhood greenness and asthma in preschool children in Kaunas, Lithuania: a case-control study. BMJ Open 6:e010341. https:// doi.org/10.1136/bmjopen-2015-010341

Annerstedt M, Norman J, Boman M, Mattsson L, Grahn P, Währborg P (2010) Finding stress relief in a forest. Ecol Bull 53:33-42

Baker AG, Zimny M, Keczyński A, Bhagwat SA, Willis KJ, Latałowa M (2016) Pollen productivity estimates from old-growth forest strongly differ from those obtained in cultural landscapes: evidence from the Białowieża National Park, Poland. Holocene 26(1):80-92. https://doi.org/10.1177/0959683615596822

Broström A (2002) Estimating source area of pollen and pollen productivity in the cultural landscapes of southern Sweden-developing a palynological tool for quantifying past plant cover. LUNDQUA thesis 46, Lund University

Bulut ND (2018) An approach to determining forest areas with recreational potential: the case of forest areas around main transportation roads in the Macka Region of Trabzon, Turkey. J Sustain For 37(3):286-301. https://doi.org/10.1080/10549811.2017.1406374

Butler CD (2008) Human health and forests: an overview. In: Colfer CJP (eds) Human health and forests. A global overview of issues, practice and policy. People and plants international. Conservation series. Earthscan, London, pp 13-33

Cariñanos P, Casares-Porcel M, Quesada-Rubio JM (2014) Estimating the allergenic potential of urban green spaces: a case-study in Granada Spain. Landscape Urban Plan, 123, 134-144. http:// www.elsevier.com/locate/landurbplan

Cariñanos P, Adinolfi A, de la Guardia CD, De Lineras C, CasarasPorcel M (2016) Characterization of allergen emission sources in urban areas. J Environ Qual 45:244-252. https://doi.org/10.2134/ jeq2015.02.0075

Cariñanos P, Casares-Porcel M, de la Guardia CD, Aira MJ, Belmonte J, Boi M, Elvira-Rendueles B, De Linares C, Fernández-Rodriguez S, Maya-Manzano JM, Perez-Badia R, Rodriguez-de la Cruz D, Rodriguez-Rajo FJ, Rojo-Ubeda J, Romero-Zarco C, SánchezReyes E, Sánchez-Sánchez J, Tormo-Molina R, Vega-Maray AM (2017) Assessing allergenicity in urban parks: a nature-based solution to reduce the impact on public health. Environ Res 155:219-227. https://doi.org/10.1016/j.envres.2017.02.015

Central Statistical Office (2014) Environment. Statistical Publishing Establishment, Warsaw, p 593

Dudek T (2013) Ocena potencjału rekreacyjnego lasów w terenie o zróżnicowanej orografii na przykładzie Czarnorzecko Strzyżowskiego Parku Krajobrazowego. [Assessment of recreational potential of forests with diverse orography: Czarnorzecko - Strzyżowski Landscape Park case study]. Sylwan 157(10): 775-779 (Abstract in English)

Dudek T (2016) Potencjał rekreacyjny lasów podmiejskich Rzeszowa wobec zapotrzebowania na wypoczynek w lasach wśród mieszkańców województwa podkarpackiego. [Recreational potential of Rzeszów suburban forests versus the demand for spending leisure time in forests among the residents of the Podkarpackie Province]. Sylwan 160(2): 169-176 (Abstract in English)

Dudek T (2017a) A study on subcarpathian voivodeship inhabitants' preferences concerning leisure time in forests. Nauka Przyroda Technologie 11(2): 153-160. https://www.npt.up-poznan.net/pub/ art 11_15.pdf

Dudek T (2017b) Recreational potential as an indicator of accessibility control in protected mountain forest areas. J Mt Sci 14(7):14191427. https://doi.org/10.1007/s11629-016-4018-z
Edwards DM, Jay M, Jensen FS, Lucas B, Marzano M, Montagné C, Peace A, Weiss G (2012) Public preferences for structural attributes of forests: towards a pan-European perspective. For Policy Econ 19:12-19. https://doi.org/10.1016/j.forpol.2011.07.006

Escobedo FJ, Kroeger T, Wagner JE (2011) Urban forests and pollution mitigation: analyzing ecosystem services and disservices. Environ Pollut 159:2078-2087. https://doi.org/10.1016/j.envpo 1.2011.01.010

Gołos P (2013) Rekreacyjna funkcja lasów miejskich i podmiejskich Warszawy. Leś Pr Bad 74(1):57-70 (Abstract in English)

Grilli G, Paletto A, De Meo I (2014) Economic valuation of forest recreation in an Alpine valley. Balt For 20(1):167-175

Hansen MM, Jones R, Tocchini K (2017) Shinrin-Yoku (forest bathing) and nature therapy: a state-of-the-art review. Int J Environ Res Public Health 14(8):851. https://doi.org/10.3390/ijerph14080851

https://www.ncbi.nlm.nih.gov/pmc/articles/PMC2793345/

Janeczko E, Woźnicka M (2009) Zagospodarowanie rekreacyjne lasów miejskich Warszawy w kontekście potrzeb i oczekiwań mieszkańców stolicy. [Development of urban forest recreation of Warsaw in the context of the needs and expectations of the residents of the capital]. Stud Mater CEPL 11(23): 131-139 (Abstract in English)

Jay M, Schraml U (2013) Managing city forests for or in spite of recreation? Perspectives of forest managers. Eur J For Res 132(1):93-105

Karjalainen E, Sarjala T, Raitio H (2010) Promoting human health through forests: overview and major challenges. Environ Health Prev Med 15: 1-8. https://www.ncbi.nlm.nih.gov/pmc/articles/ PMC2793342/

Kasprzyk I (2011) Time-series analysis of pollen seasons in Rzeszów (SE Poland) in 1997-2005 with reference to phenology. Wydawnictwo Uniwersytetu Rzeszowskiego, Rzeszów

Kikulski J (2006) Przydatność wybranych obszarów leśnych Bolimowskiego Parku Krajobrazowego do turystyki i rekreacji [The usefulness of selected forest areas of the Bolimowski Landscape Park for tourism and recreational needs]. Sylwan 150(6):40-49 (Abstract in English)

Kikulski J (2008) Preferencje rekreacyjne i potrzeby zagospodarowania rekreacyjnego lasów nadleśnictw Iława i Dąbrowa (wyniki pierwszej części badań) [The recreational preferences and needs for recreational management of forest within the Ilawa and Dabrowa Forest Districts—preliminary results]. Sylwan 152(5):60-71 (Abstract in English)

Kliskey AD (2000) Recreation terrain suitability mapping: a spatially explicit methodology for determining recreation potential for resource use assessment. Landsc Urban Plan 52(1):33-43. https ://doi.org/10.1016/S0169-2046(00)00111-0

Kondracki J (2000) Geografia regionalna Polski [Regional geography of Poland]. Wydawnictwo Naukowe PWN, Warszawa

Krzymowska-Kostrowicka A (1997) Geoekologia turystyki i wypoczynku [Geoecology of tourism and recreation]. PWN, Warszawa

Kuo M (2015) How might contact with nature promote human health? Promising mechanisms and a possible central pathway. Front Psychol 6:1093. https://doi.org/10.3389/fpsyg.2015.01093

Kuparinen A, Markkanen T, Riikonen H, Vesala T (2007) Modeling air-mediated dispersal of spores, pollen and seeds in forested areas. Ecol Model 208:177-188

Lee JH, Lee DJ (2015) Nature experience, recreation activity and health benefits of visitors in mountain and urban forests in Vienna, Zurich and Freiburg. J Mt Sci 12(6):1551-1561. https:// doi.org/10.1007/s11629-014-3246-3

Łonkiewicz B, Głuch G (1991) Wytyczne rekreacyjnego zagospodarowania lasów [Guidelines for recreational forest management]. Instytut Badawczy Leśnictwa, Warszawa

Meo I, Paletto A, Cantiani MG (2015) The attractiveness of forests: preferences and perceptions in a mountain community in 
Italy. Ann For Res 58(1):145-156. https://doi.org/10.15287/ afr.2015.308

Milleron M, Lopez de Heredia U, Lorenzo Z, Perea R, Dounavi A, Alonso J, Gil L (2012) Effect of canopy closure on pollen dispersal in wind-pollinate species (Fagus sylvatica L.). Plant Ecol 213:1715-1728. https://doi.org/10.1007/s11258-012-0125-2

Moore B, Allard G, Malagnoux M (2006) Itching for the woods: forests, allergies and irritants. Unasylva 224(57):51-55

Morita E, Nagano J, Yamamoto H, Murakawa I, Aikawa M, Shirakawa T (2009) Two thirds of forest walkers with Japanese cedar pollinosis visit forests even during the pollen season. Allergol Int 58(3):383-388. https://doi.org/10.2332/allergolint.08-OA-0050

Nielsen AB, Olsen SB, Lundhede T (2007) An economic valuation of the recreational benefits associated with nature-based forest management practices. Landsc Urban Plan 80:63-71. https://doi. org/10.1016/j.landurbplan.2006.06.003

Nordström EM, Dolling A, Skärbäck E, Stoltz J, Grahn P, Lundell Y (2015) Forests for wood production and stress recovery: tradeoffs in long-term forest management planning. Eur J For Res 134(5):755-767. https://doi.org/10.1007/s10342-015-0887-x

Nowak DJ, Crane DE, Stevens JC (2006) Air pollution removal by urban trees and shrubs in the United States. Urban For Urban Gree 4:115-123. https://doi.org/10.1016/j.ufug.2006.01.007

Ohtsuka Y, Yabunaka N, Takayama S (1998) Shinrin-yoku (forest-air bathing and walking) effectively decreases blood glucose levels in diabetic patients. Int J Biometeorol 41:125-127

Park BJ, Tsunetsugu Y, Kasetani T, Morikawa T, Kagawa T, Miyazaki Y (2009) Physiological effects of forest recreation in a young conifer forest in Hinokage Town, Japan. Silva Fenn 43:291-301

Pawankar R, Holgate TG, Canonica W, Lockey RL, Blaiss MS (eds) (2013) WOA: White Book of Allergy: Update 2013. World Allergy Organization. http://www.worldallergy.org/UserFiles/ file/WhiteBook2-2013-v8.pdf

Pidek IA (2007) Nine-year record of alnus pollen deposition in the Roztocze region (SE Poland) with relation to vegetation data. Acta Agrobot 60(2):57-64

Piotrowska K (2008) Pollen production in selected species of anemophilous plants. Acta Agrobot 61(1):41-52

Plan Urządzania Lasu (2010) Plan dla lasów Nadleśnictwa Głogów na okres 2011-2020. [Forest Management Plan (2010) Plan for the Głogów Forest District forests for 2011-2020]

Plan Urządzania Lasu (2013) Plan dla lasów Nadleśnictwa Kańczuga na okres 2014-2023. [Forest Management Plan (2013) Plan for the Kańczuga Forest District forests for 2014-2023]
Poska A, Pidek IA (2010) Pollen dispersal and deposition characteristics of Abies alba, Fagus sylvatica and Pinus sylvestris, Roztocze region (SE Poland). Veg Hist Archaeobot 19(2):91-101

Šaulienè I, Šukienė L, Kainov D, Greičiuvienė J (2016) The impact of pollen load on quality of life: a questionnaire based study in Lithuania. Aerobiologia 32(2):157-170

Skjøth CA, Sommer J, Brandt J, Hvidberg M, Geels C, Hansen KM, Hertel O, Frohn ML, Christensen JH (2008) Copenhagen-a significant source of birch (Betula) pollen? Int J Biometeorol 52(6):453-462

Subba Reddi C, Reddi NS (1986) Pollen production of some anemophilous angiosperms. Grana 25(1):55-61

Timm S, Frydenberg M, Janson C, Campbell B, Forsberg B, Gislason T, Holm M, Jogi R, Omenaas E, Sigsgaard T, Svanes C, Schlünssen V (2016) The urban-rural gradient in asthma: a populationbased study in northern Europe. Int J Environ Res Pub Health 13(1):93. https://doi.org/10.3390/ijerph13010093

Tomczyk AM, Szyga-Pluta K (2016) Okres wegetacyjny w Polsce w latach 1971-2010 [Growing seasons in Poland in the period 1971-2010]. Przeg Geogr 88(1):75-86 (Abstract in English)

van den Bosch M (2017) Natural environments, health, and well-being. Oxford Research Encyclopedia of Environmental Science. https:// doi.org/10.1093/acrefore/9780199389414.013.333

Vaz AS, Kueffer K, Kulle CA, Richardson DM, Vicentea JR, Kühn I, Schröterj M, Hauck J, Bonn A, Honrado JP (2017) Integrating ecosystem services and disservices: insights from plant invasions. Ecos Serv 23:94-107

Wilkes-Allemann J, Hanewinkel M, Pütz M (2017) Forest recreation as a governance problem: four case studies from Switzerland. Eur J For Res 136(3):511-526. https://doi.org/10.1007/s 1034 2-017-1049-0

Wójcik-Fatla A, Szymańska J, Wdowiak L, Buczek A, Dutkiewicz J (2009) Coincidence of three pathogens (Borrelia burgdorferi sensu lato, Anaplasma phagocytophilum and Babesia microti) in Ixodes ricinus ticks in the Lublin macroregion. Ann Agric Environ Med 16:151-158

Wolch JR, Byrne J, Newell JP (2014) Urban green space, public health, and environmental justice: the challenge of making cities 'just green enough'. Landsc Urban Plan 125:234-244. https://doi. org/10.1016/j.landurbplan.2014.01.017 